\title{
Exploring the nitrogen reservoir of biodegradable household garbage and its potential in replacing synthetic nitrogen fertilizers in China
}

\author{
Lan Wang ${ }^{1,2}$, Tianyu Qin ${ }^{1,2}$, Jianshe Zhao ${ }^{3}$, Yicheng Zhang ${ }^{1,2}$, Zhiyuan Wu ${ }^{1,2}$, Xiaohui Cui ${ }^{1,2}$, Gaifang Zhou ${ }^{1,2}$, \\ Caihong Li ${ }^{1}$, Liyue Guo ${ }^{\text {Corresp., }}$, Gaoming Jiang ${ }^{\text {Corresp. } 1,2}$ \\ ${ }^{1}$ State Key Laboratory of Vegetation and Environment Change, Institute of Botany, the Chinese 17 Academy of Sciences, Beijing, China \\ 2 College of Resources and Environment, University of Chinese Academy of Sciences, Beijing, China \\ 3 Henan Zhongyuan Organic Agriculture Research Institute Co., Ltd., Zhengzhou, China \\ Corresponding Authors: Liyue Guo, Gaoming Jiang \\ Email address: guoliyue6789@126.com, jgm@ibcas.ac.cn
}

Biodegradable household garbage contains a large amount of nitrogen, which could be used as organic fertilizer to produce organic food and significantly reduce synthetic nitrogen fertilizers. There is limited information on how large the nitrogen reservoir of biodegradable household garbage is in a certain country or region. Here we took China as a case, analyzed the amount of biodegradable household garbage resources and their nitrogen reservoirs. It was noted that the biodegradable household garbage mainly included food waste, waste paper and wood chips, with the amount being 31.56, 29.55, and $6.45 \times 10^{6} \mathrm{t} \cdot \mathrm{a}^{-1}$, respectively. Accordingly, the nitrogen reservoirs were $65.31 \times 10^{4}$, $6.80 \times 10^{4}$, and $3.81 \times 10^{4} \mathrm{t} \cdot \mathrm{a}^{-1}$ in China. The nitrogen reservoir of food waste accounted for $86 \%$ of the total nitrogen reservoir of biodegradable household garbage, which was equivalent to $11 \%$ of the amount of actual absorption for synthetic nitrogen fertilizers $\left(6.20 \times 10^{6} \mathrm{t} \cdot \mathrm{a}^{-1}\right)$ by agriculture plants in China. Our findings provided a scientific basis for the classification and utilization of biodegradable household garbage. 
1 Exploring the nitrogen reservoir of biodegradable household garbage and its potential in

2 replacing synthetic nitrogen fertilizers in China

3 Lan Wang ${ }^{1,2}$, Tianyu Qin ${ }^{1,2}$, Jianshe Zhao ${ }^{3}$, Yicheng Zhang ${ }^{1,2}$, Zhiyuan $\mathrm{Wu}^{1,2}$, Xiaohui Cui ${ }^{1,2}$,

4 Gaifang Zhou ${ }^{1,2}$, Caihong $\mathrm{Li}^{1}$, Liyue Guo ${ }^{1 *}$, Gaoming Jiang ${ }^{1,2} *$

5 (1. State Key Laboratory of Vegetation and Environment Change, Institute of Botany,

6 the Chinese Academy of Sciences, Beijing, 100093, China

7 2. College of Resources and Environment, University of Chinese Academy of Sciences, Beijing,

8 100049, China

9 3. Henan Zhongyuan Organic Agriculture Research Institute Co., Ltd.,

10 Zhengzhou, 450043, China)

11 * Corresponding author:

12 Gaoming Jiang, Tel.: +8610-6283-6286, fax: +8610-8259-6146. E-mail address:

13 jgm@ibcas.ac.cn

14 Liyue Guo, Tel.: +8610-6283-6555, fax: +8610-8259-6146. E-mail address:

15 guoliyue@,ibcas.ac.cn

\section{Abstract}

17 Biodegradable household garbage contains a large amount of nitrogen, which could be used as organic fertilizer to produce organic food and significantly reduce synthetic nitrogen fertilizers.

19 There is limited information on how large the nitrogen reservoir of biodegradable household garbage is in a certain country or region. Here we took China as a case, analyzed the amount of biodegradable household garbage resources and their nitrogen reservoirs. It was noted that the biodegradable household garbage mainly included food waste, waste paper and wood chips, with 
23 the amount being 31.56, 29.55, and $6.45 \times 10^{6} \mathrm{t} \cdot \mathrm{a}^{-1}$, respectively. Accordingly, the nitrogen

reservoirs were $65.31 \times 10^{4}, 6.80 \times 10^{4}$, and $3.81 \times 10^{4} \mathrm{t} \cdot \mathrm{a}^{-1}$ in China. The nitrogen reservoir of food waste accounted for $86 \%$ of the total nitrogen reservoir of biodegradable household garbage, which was equivalent to $11 \%$ of the amount of actual absorption for synthetic nitrogen fertilizers $\left(6.20 \times 10^{6} \mathrm{t} \cdot \mathrm{a}^{-1}\right)$ by agriculture plants in China. Our findings provided a scientific basis for the classification and utilization of biodegradable household garbage.

Keywords: Household garbage; Food waste; Biomass nitrogen reservoir; Agricultural sustainable development

\section{Introduction}

Modern agriculture is mainly characterized with large utilization of synthetic chemical substances such as fertilizers, pesticides, and herbicides. Although the crop yields have been increased by chemical substances, the long-term application of those chemicals has caused serious adverse effects on soil, air, water, food, even human health. Soil acidification (Guo et al. 2010; Sutton et al. 2011), greenhouse gas emission (Parihar et al. 2018), water eutrophication (Hansen et al. 2019) and pesticide residues (Urso and Gilbertson 2018) in agricultural system have been frequently reported. As a result, the quality of food, the nutritional contents (Yu et al. 2018), and the incomes of agriculture have been largely decreased (Stuart and Houser 2018). To a certain extent, cheaper food lead to more food waste. For instance, today, food mixed with garbage become the main components of modern urban and rural household garbages.

In the world, a large amount of household garbage is produced every day, which causes serious environmental pollution, and cost a lot of lands and money to handle (Du et al. 2018). 
44 According to the statistics of the World Bank, the amount of household garbage generated

45 worldwide reached to $2.01 \times 10^{9} \mathrm{t} \mathrm{a}^{-1}$ in 2016. In China, $4 \times 10^{8} \mathrm{t} \cdot \mathrm{a}^{-1}$ household garbages (fresh

46 weight) have been produced, while the disposal rate was far behind its rate of generation (Wu et

47 al. 2018).

The accumulation of household garbage has resulted in increasing environmental pollution,

affecting the lives of residents and harming human health (Hiramatsu et al. 2009; Rao and

Rathod 2019). Actually, the household garbage has an abundance of nutrients, including organic

matter $(39.05 \%)$, nitrogen $(1.02 \%)$, phosphorus $(0.50 \%)$ and potassium $(1.42 \%)$ (Han et al.

2019). Nitrogen, an essential nutrient for plants growth, is the key element in the agricultural

ecosystem (Sharma and Bali 2018), particularly in poor soils which need more exogenous

nitrogen as an essential nutrient (Zeng et al. 2020). Globally, 1.50-2.00 $\times 10^{8} \mathrm{t} \mathrm{a}^{-1}$ mineral

nitrogen is required to produce grains, feed animals and be used as industrial products (Aulakh et

al. 2017). Nowadays, the demand for nitrogen is mainly met by applying synthesized nitrogen

fertilizers (Lu and Tian 2017). If the biodegradable household garbage was utilized as organic

fertilizer, we would reduce the application amount of synthesized nitrogen at a certain level.

known as municipal solid waste, includes food waste, recyclables, hazardous waste and others.

However, the largest proportion in municipal solid waste is food waste, accounting to $61.2 \%$ of

the total (Gu et al. 2017). The main components of rural household garbage in China include

inert waste, food waste, glass and paper (Han et al. 2019). Regardless of urban or rural household

garbage, biodegradable food waste accounts for a large proportion (Gallipoli et al. 2010), with 
65 the main components being carbohydrate polymers (starch, cellulose, hemicellulose), proteins,

66

67 organic acids, lignin, lipids, etc. Those biological materials can be decomposed into reducing sugars, free amino acids, phosphates and nitrates under the action of microbial hydrolysis which could be absorbed by agriculture plants (Xing et al. 2019). In addition, food waste has low content of salts and heavy metals, which might be directly used as organic fertilizer (Xiong 2015).

Among 94 countries in the world, China takes a leading position in the amount of food waste, followed by the United States and South Korea (Zhang et al. 2018). However, intensive researches have just forcused on the technology innovation, management methods and bioenergy utilization potentials of food waste, in some countries such as the United States (Breunig et al. 2017), South Korea (Seo et al. 2019), and Ireland (Dennehy et al. 2017), Turkey (Guven et al. 2019), etc. In many European countries, there were more reports on food waste composting technology (Ghinea et al. 2019), and food waste collection methods (Cecchi and Cavinato 2019). Although the UK had the most detailed, directly measured household food waste data, only the nutrients and energy content had been calculated (Cooper et al. 2018). Some investigators from Italy (Stathopoulos 2017; Giordano et al. 2019) and Canada (von Massow et al. 2019; Heidari et al. 2020) analyzed the main behaviors and attitudes based on the amount of food waste.

Nevertheless, there was no statistics on the overall nitrogen reservoir. It is still not clear the resources and nitrogen reservoir of the biodegradable components of household garbage in the developing countries like China. The potential of replacing chemical fertilizers has been seldom reported, so the relevant scientific research is urgently needed. 
The scientific hypothesis of this paper was that the biodegradable household garbage

87 contained a large amount of nitrogen resources that could significantly replace the synthetic nitrogen fertilizers to develop organic agriculture. The treatment of biodegradable household garbage and the development of organic agriculture could be perfectly unified with the help of farmland. This study tried to use the statistical data to reveal: 1) The biodegradable components and resources in urban and rural household garbage together with the nitrogen reservoir in China; 2) The potential of biodegradable household garbage in replacing chemical fertilizers. This study might provide scientific basis for both the utilization of household garbage resources and the health development of organic agriculture.

\section{Materials \& Methods}

\subsection{Data Sources}

The biodegradable household garbage was divided into urban and rural one. According to the composition and characteristics, the biodegradable garbage was further divided into three categories, i.e., food waste, waste paper and wood chips ( Li et al. 2019). Data were collected as previously described in Cui date (Cui et al. 2021). Specifically the original data mainly came from: China Statistical Yearbook (2011-2020) and China Statistical Yearbook on Urban and Rural Construction (2011-2020). The rest of related information was obtained by searching "household garbage", "biodegradable household garbage", and "food waste" through "Web of Science" and "Chinese National Knowledge Infrastructure (CNKI)". Because of the special statistical system and the situation of China, all data reported in this paper were included except Hong Kong, Macau and Taiwan. 
107

108

109

110

111

112

113

114

115

116

117

118

119

120

121

122

123

124

125

126

127

2.2 Food waste resources and the nitrogen reservoir

The total amount of food waste resources contained urban and rural one. The former was calculated by multiplying urban household garbage by the proportion of urban food waste in urban household garbage. The latter was calculated by multiplying the rural population by the average daily waste generation per capita, the number of days per year and the ratio of rural food waste to rural household garbage. The nitrogen reservoir of food waste was calculated by multiplying the total amount of food waste by its average nitrogen content.

$\mathrm{TF}=(\mathrm{UF}+\mathrm{RF}) \times(1-w 1)=(\mathrm{UG} \times \mathrm{a} 1+\mathrm{RG} \times \mathrm{b} 1) \times(1-w 1)=(\mathrm{UG} \times \mathrm{a} 1+\mathrm{RP} \times \mathrm{DG} \times D \times \mathrm{b} 1)$

$\times(1-w 1)$

$\mathrm{TN} 1=\mathrm{TF} \times \alpha 1$

Where TF is the total output of urban and rural food waste each year; UF is the the output of urban food waste; RF is the output of rural food waste; UG is the output of urban household garbage; RG is the output of rural household garbage; RP is the number of rural population; DG is the per capita daily garbage production; al is the proportion of urban food waste in urban household garbage (61.20\%) ( $\mathrm{Gu}$ et al. 2017); b1 is the proportion of rural food waste in rural household garbage (33.7\%) (Wu et al. 2018); $D$ is the total days of the year; $w 1$ is water content (82\%) (Gallipoli et al. 2020); TN1 is the total urban and rural food waste nitrogen reservoir; $\alpha 1$ is average nitrogen content of food waste (2.07\%) ( Adhikari et al. 2009; Yang et al. 2013;

Zhang et al. 2016).

2.3 Waste paper resources and the nitrogen reservoir The total amount of waste paper resources was composed of urban waste paper and rural 
128

129

130

131

132

133

134

135

136

137

138

139

140

141

142

143

144

145

146

147

148

waste one. The former was calculated by multiplying urban household garbage by the proportion of urban waste paper in urban household garbage. The latter was calculated by multiplying the rural population by the average daily waste generation per capita, the number of days per year and the ratio of rural waste paper to rural household garbage. The nitrogen reservoir of waste paper was calculated by multiplying the total amount of waste paper by its average nitrogen content.

$\mathrm{TP}=(\mathrm{UP}+\mathrm{RP}) \times(1-w 2)=(\mathrm{UG} \times \mathrm{a} 2+\mathrm{RG} \times \mathrm{b} 2) \times(1-w 2)=(\mathrm{UG} \times \mathrm{a} 2+\mathrm{RP} \times \mathrm{DG} \times$

$D \times \mathrm{b} 2) \times(1-w 2)$

$\mathrm{TN} 2=\mathrm{TP} \times \alpha 2$

Where TP is the total output of urban and rural waste paper each year; UP is the the output of urban waste paper; RP is the output of rural waste paper; UG is the output of urban household garbage; RG is the output of rural household garbage; RP is the number of rural population; DG is the per capita daily garbage production; a2 is the proportion of urban waste paper in urban household garbage $(9.6 \%$ ) ( Gu et al. 2017); b2 is the proportion of rural waste paper in rural household garbage (10.75\%) (Wu et al. 2018); $D$ is the total days of the year; $w 2$ is water content (7.35\%) (Ding et al. 2013); TN2 is the total urban and rural waste paper nitrogen reservoir; $\alpha 2$ is average nitrogen content of waste paper (0.23\%) (Ding et al. 2013).

2.4 Wood chip resources and the nitrogen reservoir

The total amount of wood chips resources was composed of urban wood chips and rural ones. The former was calculated by multiplying urban household garbage by the proportion of urban wood chips in urban household garbage. The latter was calculated by multiplying the rural 
149

150

151

152

153

154

155

156

157

population by the average daily waste generation per capita, the number of days per year and the ratio of rural wood chips to rural household garbage. The nitrogen reservoir of wood chips was calculated by multiplying the total amount of wood chips by their average nitrogen content.

$$
\mathrm{TW}=(\mathrm{UW}+\mathrm{RW}) \times(1-w 3)=(\mathrm{UG} \times \mathrm{a} 3+\mathrm{RG} \times \mathrm{b} 3) \times(1-w 3)=(\mathrm{UG} \times \mathrm{a} 3+\mathrm{RP} \times \mathrm{DG} \times
$$

$D \times \mathrm{b} 3) \times(1-w 3)$

$\mathrm{TN} 3=\mathrm{TW} \times \alpha 3$

Where TW is the total output of urban and rural wood chips each year; UW is the the output of urban wood chips; RW is the output of rural wood chips; UG is the output of urban household garbage; $\mathrm{RG}$ is the output of rural household garbage; $\mathrm{RP}$ is the number of rural population; $\mathrm{DG}$ is the per capita daily garbage production; $a 3$ is the proportion of urban wood chips in urban household garbage (1.8\%) ( Gu et al. 2017); b3 is the proportion of rural wood chips in rural household garbage (3.23\%) (Wu et al. 2018); $D$ is the total days of the year; $w 3$ is water content (7.24\%) (Zhou et al. 2018); TN3 is the total urban and rural wood chips nitrogen reservoir; $\alpha 3$ is average nitrogen content of wood chips (0.59\%) (Zhou et al. 2018).

2.5 Total biodegradable household garbage nitrogen reservoir

The total nitrogen reservoir of urban and rural biodegradable household garbage included urban and rural food waste nitrogen reservoir, waste paper nitrogen reservoir, and wood chips nitrogen reservoir, which was calculated as followings:

$\mathrm{TN}=\mathrm{TN} 1+\mathrm{TN} 2+\mathrm{TN} 3$

$\mathrm{TN}$ is the total urban and rural biodegradable household garbage nitrogen reservoir; TN1 is the total urban and rural food waste nitrogen reservoir; TN2 is the total urban and rural waste 
170

171

172

173

174

175

176

177

178

179

180

181

paper nitrogen reservoir; TN3 is the total urban and rural wood chips nitrogen reservoir.

2.6 Statistical analysis

Microsoft Excel 2007 was applied to process the data. SPSS 20.0 (SPSS Inc, Chicago, IL, USA) was applied to analyse the data. Figures were generated using SigmaPlot 12.5 (Systat Software Inc., San Jose, CA, USA).

\section{Results}

3.1 Food waste resource and its nitrogen reservoir

The total amount of urban and rural household garbage resources in China dated from 2010 to 2019 was shown in Table 1. According to formula (1), the amount of urban and rural food waste (dry weight) in China had been increasing year by year, reaching to $3.16 \times 10^{7} \mathrm{t} \cdot \mathrm{a}^{-1}$ in 2019 . As well, the amount of urban food waste continued to grow, reaching to $2.67 \times 10^{7} \mathrm{t} \cdot \mathrm{a}^{-1}$ in 2019 .

Compared with 2010 , the urban food waste increased by $53 \%$, accounting $88 \%$ of the total food waste. However, as more and more rural people flooded into cities, the amount of rural food waste decreased, from $5.94 \times 10^{6} \mathrm{t} \cdot \mathrm{a}^{-1}$ in 2010 to $4.89 \times 10^{6} \mathrm{t} \cdot \mathrm{a}^{-1}$ in 2019 (Fig 1). According to formula (2), the nitrogen reservoir of food waste had been also increasing yearly, reaching to $6.51 \times 10^{5} \mathrm{t} \cdot \mathrm{a}^{-1}$ in 2019 (Fig 1).

3.2 Waste paper resource and its nitrogen reservoir

It was noted that the amount of urban waste paper resources elevated from $1.41 \times 10^{7} \mathrm{t} \cdot \mathrm{a}^{-1}$ in 2010 to $2.15 \times 10^{7} \mathrm{t} \cdot \mathrm{a}^{-1}$ in 2019 after calculated by formula (3). The amount of rural waste paper resource decreased from $9.76 \times 10^{6} \mathrm{t} \cdot \mathrm{a}^{-1}$ to $8.02 \times 10^{6} \mathrm{t} \cdot \mathrm{a}^{-1}$. The total amount of urban and rural waste paper resources increased year by year, reaching to $2.96 \times 10^{7} \mathrm{t} \cdot \mathrm{a}^{-1}$ in 2019 . According to 
191 formula (4), the nitrogen reservoir of waste paper increased with the increase of waste paper

192 resource, reaching to $6.80 \times 10^{4} \mathrm{t} \cdot \mathrm{a}^{-1}$ in 2019 (Fig 2).

1933.3 Wood chips resource and its nitrogen reservoir

194 From 2010 to 2019 , the amount of urban wood chips increased from $2.64 \times 10^{6} \mathrm{t} \cdot \mathrm{a}^{-1}$ to 4.04

$195 \times 10^{6} \mathrm{t} \cdot \mathrm{a}^{-1}$ after calculated by formula (5). The amount of rural wood chips decreased from 2.94

$196 \times 10^{6} \mathrm{t} \cdot \mathrm{a}^{-1}$ to $2.41 \times 10^{6} \mathrm{t} \cdot \mathrm{a}^{-1}$. The total amount of wood chips in urban and rural increased yearly,

197 reaching to $6.45 \times 10^{6} \mathrm{t} \cdot \mathrm{a}^{-1}$ in 2019 . According to formula (6), the wood chip nitrogen reservoir

198 increased to $3.81 \times 10^{4} \mathrm{t} \cdot \mathrm{a}^{-1}$ in 2019 (Fig 3).

1993.4 The total nitrogen reservoir of biodegradable household garbage and its components

200 It was found that the total nitrogen reservoir of urban and rural biodegradable household

201 garbage in China had been increasing since 2010. In 2019, the nitrogen reservoir was $75.92 \times 10^{4}$

$202 \mathrm{t} \cdot \mathrm{a}^{-1}$, increased by $33 \%$ compared with that of 2010 (Fig 4). For the components, urban and rural

203 biodegradable household garbage were composed of food waste, waste paper and wood chips,

204 among which food waste accounted for $84 \%-86 \%$, waste paper $8 \%-9 \%$ and wood chips $5 \%-6 \%$.

205 The proportion of food waste had been increasing, while the proportion of waste paper and wood

206 chips had been decreasing from 2010 to 2019 (Fig 4).

2073.5 Yearly rates of changes in biodegradable household garbage resources

208 From 2010 to 2019, the yearly changes of urban biodegradable household garbage resources

209 had increased while that of rural had decreased in China (Table 2). From 2014 to 2015, the

210 yearly rate of increase in urban biodegradable household garbage resources was the maximum.

211 From 2016 to 2017, however, the yearly rate of decrease in rural household gargage was the 
212 maximum.

213 3.6 Per capita biodegradable household garbage resources in seven regions of China

214 In 2019, the amount of urban and rural food waste, waste paper, wood chips and the per

215 capita biodegradable household garbage resources in seven regions of China were shown in

216 Table 3. The largest amount of biodegradable household garbage and the per capita

217 biodegradable household garbage were from east and sourthern China, respectively, with the

218 least being from northwest China.

2193.7 The relationship between per capital GDP and per capital discharge of food waste

Among the biodegradable household garbage, food waste accounted for the largest

proportion, which was the most promising renewable resource as organic fertilizer. In 2019, the

amount of urban and rural food waste resources in different provinces of China were shown in

Table 4 (Provincial scale). The top five provinces with the largest amount of food waste were

from Guangdong, Jiangsu, Shandong, Zhejiang and Henan. As one of most developed provinces

in China, Guangdong had the maximum food waste discharg of $3.98 \times 10^{6} \mathrm{t} \cdot \mathrm{a}^{-1}$, accounting for

$13 \%$ of the total food waste of the country.

There was a pretty significant linear positive correlation between the per capital GDP and

per capital discharge of food waste $(P<0.01)$ (Fig 5). The per capital GDP values of different

provinces were found to be mostly relevant with per capital food waste. The more GDP

increased, the more foods were wasted, indicating that the fast development of economy was

based on the huge waste of food resources which further led to environmental pollutions.

\section{Discussion}


233

234

4.1 Components and treatments of urban and rural degradable household garbage

Economic development, urbanization, and the living standards improvement of human being have led to a sharp increase in the amount of household garbage discharge, especially in developed countries (Breunig et al. 2017). To a certain extent, the discharge of household garbage is restricted by socio-economic conditions (Huang et al. 2013) and geographical locations (Han et al. 2015). Unfortunately, the developing countries have been following the footsteps of developed countries, with their garbage waste being increased rapidly (Rai et al. 2019). Most of cities in the world have struggled to "Garbage siege". Unlike urban residents, rural residents have maintained a high utilization rate of those materials (Ma et al. 2018). In 2019, the total amount of urban and rural household garbage reached to $3.23 \times 10^{8} \mathrm{t} \cdot \mathrm{a}^{-1}$ in China (Table 1).

At present, the methods for treating urban household garbage mainly include incineration, landfill, composting, etc.(Zhang, 2019). In the rural China, however, there is still a shortage of appropriate infrastructure and solid waste management (Hiramatsu et al. 2009). Most rural household garbages are randomly discarded without any treatments, resulting in increase of environmental pollution and damage of human health (Cao et al. 2018).

Implementing household garbage classification which follows the principles of reduction, recycling, and harmlessness, is believed to be an effective approach to improve the urban and rural environments and promote resource recycling (Shi et al. 2020). However, it achieved limited effect, dispite of enough mobilization has been done by the government, as urban and rural residents always believe that garbage disposal is the government's business not theirs. 
254 According to the compositions and characteristics of household garbage, urban and rural

255 degradable household garbages are divided into food waste, waste paper and wood chips (Li et

256 al. 2019). We here found these resources in China were respectively $31.56,29.55$ and $6.45 \times 10^{6}$

$257 \mathrm{t} \cdot \mathrm{a}^{-1}$. In 2019, the total amount of the biodegradable household garbage was $67.4 \times 10^{6} \mathrm{t} \cdot \mathrm{a}^{-1}$ in

258 China (Table 3). The urban biodegradable household garbage was on the rise over time (Table

259 2).

260 Urban and rural wood chips, as a kind of biomass, can be used as adsorbents for treating

waste water, which reduces waste water treatment costs while increases environmental benefits

(Li et al. 2010). Waste wood chips could be also converted into gaseous or liquid fuel, chemical

raw materials and other products through thermochemical, chemical, and biological methods (Xu

et al. 2018). Waste paper, however, is an ideal recyclable renewable resource that can be used for

paper-making, wood production, or terated as various functional materials (Liu 2016). In order to

increase the utilization rate of paper, those waste papers are normally reused, even recycled,

which could reduce the amount of felling of trees and obtain more ecological benefits (Liu

2018). Therefore, the utilization of waste wood chips and waste paper follows a mode of circular

economy. The application of such waste in the environmental protection industry should be

continuously more strengthened rather than be used as fertilizers.

271 Food waste is the main component of urban and rural household garbage, which is also one

272 of the most promising renewable resources (Cecchi and Cavinato 2019). In the U.S. wastes about

$27363 \times 10^{6} \mathrm{t} \cdot \mathrm{a}^{-1}$ of food wasted (Dusoruth and Peterson 2020), South Korea watstes about $5 \times 10^{6}$

$274 \mathrm{t} \cdot \mathrm{a}^{-1}$ food (Lee et al. 2019), in Europe approximately $10.0 \times 10^{7} \mathrm{t} \cdot \mathrm{a}^{-1}$ of food are wasted (Zhang et 
275 al. 2018). Food waste reached to $3 \cdot 16 \times 10^{7} \mathrm{t} \cdot \mathrm{a}^{-1}$ in 2019 in China (dry weight). Much of the food

276 waste is a result of urbanization, for instance, urban food waste in China was as large as 2.67

$277 \times 10^{7} \mathrm{t} \cdot \mathrm{a}^{-1}$, while rural food waste was only $4.89 \times 10^{6} \mathrm{t} \cdot \mathrm{a}^{-1}$ in the year of 2019 (Fig 1 ). Food waste

278 can be treated by landfill, incineration and composting (Han et al. 2015). However, landfill is

279 likely to bring about greenhouse gases emissions, generation of large amount of leachate, and

280 finally environmental pollution (Ma and Liu 2019). Although incineration could reduce the

volume of food waste, it needs a high demand for energy and might produce harmful substances

282

283

284

285

286

287

288

289

290

291

292

293

294

295

and greenhouse gasses (Liu et al. 2019).

Aerobic composting is a relatively environmentally friend technology for food waste

treatment, as foods contain high concentrations of easily degradable organic substances and

nutrients which are easily to be decomposed (Hou et al. 2017). Studies have found that food

waste composted with Chinese medicinal herbal residues (Zhou et al. 2018), green waste

(Williams et al. 2019), sugarcane leaves (Shan et al. 2019), cattle manure (Xing et al. 2019), pig

manure (Dennehy et al. 2017; Jiang et al. 2018), chicken manure (Saad et al. 2019) could be

processed to form biological fertilizers, which would increase organic matters in the soil and

improve the soil structure (Wang and Zeng 2018). Therefore, the degradable food waste,

especially rural food waste could be used on-site as fertilizers for organic crop production, which

can largely reduce transportation and treatment costs and increase farmers' income as well.

4.2 Nitrogen reservoir of biodegradable household garbage in different components

In China, food waste accounted for the largest proportion $(84 \%-86 \%)$ of the nitrogen

reservoir of biodegradable household garbage, followed by waste paper and wood chips. Along

Peer] reviewing PDF | (2021:07:63776:1:1:NEW 2 Nov 2021) 
296

297

298

299

300

301

302

303

304

305

306

307

308

309

310

311

312

313

314

315

316

with time, the proportion of food waste increased, while waste paper and wood chips declined

(Fig 4). In 2019, we found that the nitrogen reservoir of food waste, waste paper and wood chips in China were $65.31 \times 10^{4}, 6.80 \times 10^{4}$, and $3.81 \times 10^{4} \mathrm{t} \cdot \mathrm{a}^{-1}$, respectively.

The nitrogen in food waste was mainly organic one, which was found in various molecular forms, such as protein, amino acid, and nucleic acid, etc. (Wang and Zeng 2018). It was reported that the protein content of food waste was $20 \%$ (Waqas et al. 2019) and $\mathrm{NH}_{4}{ }^{+}-\mathrm{N}$ was $2800 \mathrm{mg}$ $\mathrm{kg}^{-1}$ (Rigby and Smith 2013). Nitrate is the main form of nitrogen absorption and utilization by most crops in cultivated soils (Andrews et al. 2013). So, as a source of biomass nitrogen, food waste can be used in organic agriculture to improve soil quality and promote agricultural development.

4.3 Potential of biodegradable household garbage of replacing synthetic nitrogen fertilizers Among the biodegradable household garbage, wood chips and waste paper could be recycled, which play more important roles in the environmental protection industry rather than used as fertilizers. Therefore, this article did not consider them as organic fertilizers. During fermentation process, various components in food waste are converted into stable humus-like substances and rapidly available nutrients, which can be quickly hydrolyzed (Bi et al. 2019), or directly absorbed by plants (Hou et al. 2017). Those materials could also improve nutrition levels of the soil (Du et al. 2018) and could be generally beneficial to soil microbial communities (Liu et al. 2020) which are closely related to soil fertility. Soil microorganisms provide a variety of services for agriculture ecosystem, such as cycling of nutrient elements, degradation of pesticides, suppression of plant diseases, and promotion of plant growth (Ding et al. 2019). In 
317 food waste, the dissolved organic matter is very active, which directly provides energy for

318 microbes (Shan et al. 2019). Therefore, food waste is regarded as an ideal and cheap raw

319 material for the production of biological fertilizers (Ma and Liu 2019). It was documented that

320 the rapid humification of food waste prepared as a soil conditioner could significantly improve

321 the total organic carbon content in orchard soils (Jia et al. 2019). Some also found that food

322 waste culture medium could replace inorganic culture medium as a nutrient supplement to

323 cultivate chlorella and improve nutrient utilization efficiency (Chew et al. 2018). The organic

324 fertilizer processed by food waste and substrate in different ratios could promote the growth of

325 potted vegetables pepper (Capsicum annuum) and cabbage (Brassica pekinensis) (Li et al. 2020).

326 In addition, some investigators who directly applied food waste to potting soil found that food

327 waste promoted leaf growth of Chlorophytum comosum, and increased soil available nitrogen,

328 phosphorus and potassium (Song et al. 2014). Therefore, the ability of food waste in producing

329 organic foods suggested here might be an alternative and effective way of treating biodegradable

330 household garbage in the future.

331 Just recently, our team had proposed that biomass resources originally produced by

332 photosynthesis and their biodegradable derivatives such as biodegradable household garbage,

333 can be all used as organic fertilizers which have huge potentials in replacing chemical ones (Cui

334 et al. 2021). Under the action of microorganism, the organic matter in the food waste will be

335 rapidly decomposed into substances that can be easily absorbed by agriculture plants, thus partly

336 replacing the usage of chemical fertilizers. In China, the actual amount of chemically synthesized

337 nitrogen fertilizer absorbed by agricultural plants nationwide was $6.20 \times 10^{6} \mathrm{t} \cdot \mathrm{a}^{-1}$. Food waste, if 
338 applied as organic fertilizers, could replace $11 \%$ of chemical nitrogen application. Especially, the

339 rural food waste when simply stacked, processed and returned directly to the farmland, could

340 save processing and transportation costs. This will not only fully make use of household garbage,

341 but also make up for the lack of organic fertilizers in the development of organic farming, so as

342 to ensure food security.

$343 \quad 4.4$ The relationship between GDP and food waste

344 Food waste occurs at all stages of the supply chain which is affected by many factors, such

345 as geography and economy, production systems, infrastructure, markets, and consumption

346 (Bonadonna et al. 2019). Larger consumer market and more consumption input undoubtedly

347 exacerbate the food waste (Di Talia et al. 2019).

348 Our study displayed that there was a very significant linear positive correlation between the

349 per capital GDP and per capital food waste production (Fig 5). GDP is mainly based on the

classification of cities based on the concentration of commercial resources, diversity of lifestyles,

future plasticity, urban hubs, and urban occupant activity index in China (Wang 2018). Our

findings demonstrated that the GDP and food waste generation of economically developed

provinces were much higher than those of underdeveloped provinces (Fig 5). And the largest

amount of per capita biodegradable household garbage was in the sourthern China of the seven

regions of the country (Table 3). This might be owing to its own economic conditions and

geographical location. Southern China has been mostly economically developed, with the

amount of waste generated remaining the highest over the years (Tian et al., 2018).This situation

is consistent with that of the United States (Breunig et al. 2017). Food waste contains biomass 
359

360

361

362

363

364

365

366

367

368

369

370

371

372

373

374

375

376

377

nitrogen which could be used again for food production after simple treatment. If well paid, farmers might be actively mobilized and engaged in organic farming, so as to implement waste sorting and utilization at the source, reduce the load of rural waste entering to cities and cut down waste disposal costs.

\subsection{Questions and suggestions}

So far, most investigations on food waste treatments usually focus on energy recovery.

However, they do not consider the economic feasibility of such an approach (Ma and Liu 2019).

Food waste can be easily collected from various sources such as food processing industries, households, and hospitality sectors (Paritosh et al. 2017; Sindhu et al. 2019). Nevertheless, food waste may contain some inert materials, such as glass or plastic, and the distribution is somewhat difficult.

Although the prices of organic food are much higher and farmers are willing to invest their labors to use food waste in organic farming, correct collection, storage, and distribution are major obstacles of food waste management. To overcome those shortages, we here suggest: 1) The government should improve the household garbage collection and classification system in rural areas, and encourage farmers to use biodegradable household garbage in organic farming. By doing so, almost $80 \%$ of the degradable garbage in China could used as organic fertilizers to produce organic foods, thus uniting the ecological and economic chains together; 2) In cities, the government should encourage companies to build special food waste treatment plants to solve the problem of destination of urban household garbage by market-based means; 3) The government should supplement waste disposal subsidies to enterprises or farmers who produce 
380

381

382

383

384

385

386

387

organic food using the degraded food waste, if they have actually reduced the amount of biodegradable waste.

\section{Conclusions}

The total amount of urban and rural biodegradable household garbage in China was 6.76 $\times 10^{7} \mathrm{t} \cdot \mathrm{a}^{-1}$, with the nitrogen reservoir being $7.59 \times 10^{5} \mathrm{t} \cdot \mathrm{a}^{-1}$. The nitrogen reservoir of food waste potentially used as organic fertilizers reached to $6.53 \times 10^{5} \mathrm{t} \cdot \mathrm{a}^{-1}$, being equivalent to $11 \%$ of the amount of actual absorption for synthetic nitrogen fertilizers $\left(6.20 \times 10^{6} \mathrm{t} \cdot \mathrm{a}^{-1}\right)$ by agriculture plants of the country. There was a singificant correlation between per capital GDP and the per capital food waste. Food waste from household garbage should be classified and processed at the source, economically used as organic fertilizers to replace chemical ones. Our innovative solution might realize the recycling of biodegradable waste and the sustainable development of agriculture, ensure both food security and environmental protection.

\section{Acknowledgement}

We thank all the staffs of Hongyi Organic Farm for providing accommodation and the field facilities, especially Mr. Jiang Gaoliang and Mr. Jiang Shenglin. We also thank all the researchers who given us help during the study.

\section{References}

Adhikari BK, Barrington S, Martinez J, King S. 2009. Effectiveness of three bulking agents for food waste composting. Waste Management 29:197-203. DOI: 10.1016/j.wasman.2008.04.001

Andrews M, Raven JA, Lea PJ. 2013. Do plants need nitrate? The mechanisms by which nitrogen form affects plants. Annals of Applied Biology 163:174-199. 
402

403

404

405

406

407

408

409

410

411

412

413

414

415

416

417

418

419

420

421

422

423

424

425

DOI: $10.1111 / \mathrm{aab} .12045$

Aulakh MS, Garg AK, Manchanda JS, Dercon G, Nguyen ML. 2017. Biological nitrogen

fixation by soybean and fate of applied $\mathrm{N}^{15}$-fertilizer in succeeding wheat under conventional tillage and conservation agriculture practices. Nutrient Cycling in Agroecosystems 107:79-89. DOI: 10.1007/s10705-016-9816-8

Bi SJ, Hong XJ, Bai Y, Liu JL, Yu XH, Fang SM, Gao YM, Yan L, Wang ZH, Wang YJ, Wang WD. 2019. Methane production dynamics of co-digestion of cow manure and food waste under mesophilic condition. Journal of Biobased Materials and Bioenergy 13:257-263. DOI: $10.1166 /$ jbmb.2019.1846

Bonadonna A, Matozzo A, Giachino C, Peira G. 2019. Farmer behavior and perception regarding food waste and unsold food. British Food Journal 121:89-103. DOI:10.1108/bfj-12-20170727

Breunig HM, Jin L, Robinson A, Scown CD. 2017. Bioenergy potential from food waste in California. Environmental Science \& Technology 51:1120-1128.

DOI: 10.1021/acs.est.6b04591

Cao S, Xu DD, Liu SQ. 2018. A study of the relationships between the characteristics of the village population structure and rural residential solid waste collection services: Evidence from China. International Journal of Environmental Research and Public Health 15:17. DOI: $10.3390 /$ ijerph15112352

Cecchi F, Cavinato C. 2019. Smart approaches to food waste final disposal. International Journal of Environmental Research and Public Health 16:13. DOI: 10.3390/ijerph16162860

Chen HB, Jiang W, Yang Y, Yang Y, Man X. 2017. State of the art on food waste research: a bibliometrics study from 1997 to 2014. Journal of Cleaner Production 140:840-846. DOI:10.1016/j.jclepro.2015.11.085 
426

427

428

429

430

431

432

433

434

435

436

437

438

439

440

441

442

443

444

445

446

447

Chew KW, Chia SR, Show PL, Ling TC, Arya SS, Chang JS. 2018. Food waste compost as an organic nutrient source for the cultivation of Chlorella vulgaris. Bioresource Technology 267:356-362. DOI: 10.1016/j.biortech.2018.07.069

Cooper KA, Quested TE, Lanctuit H, Zimmermann D, Espinoza-Orias N, Roulin A. 2018.

Nutrition in the bin: A nutritional and environmental assessment of food wasted in the

UK. Frontiers in Nutrition 5:19 doi:10.3389/fnut.2018.00019

Cui XH, Guo LY, Li CH, Liu MZ, Wu GL, Jiang GM. 2021. The total biomass nitrogen reservoir and its potential of replacing chemical fertilizers in China. Renewable \& Sustainable Energy Reviews 135:110215. DOI: 10.1016/j.rser.2020.110215

Dennehy C, Lawlor PG, Gardiner GE, Jiang Y, Shalloo L, Zhan X. 2017. Stochastic modelling of the economic viability of on-farm co-digestion of pig manure and food waste in Ireland. Applied Energy 205:1528-1537. DOI: 10.1016/j.apenergy.2017.08.101

Di Talia E, Simeone M, Scarpato D. 2019. Consumer behaviour types in household food waste. Journal of Cleaner Production 214:166-172. DOI:10.1016/j.jclepro.2018.12.216

Ding GC, Bai MH, Han H, Li HX, Ding XY, Yang HF, Xu T, Li J. 2019. Microbial taxonomic, nitrogen cycling and phosphorus recycling community composition during long-term organic greenhouse farming. FEMS Microbiology Ecology 95:12.

DOI: $10.1093 /$ femsec/fiz042

Ding K, Zhong ZP, Yu LL, Liu ZC. 2013. Pyrolysis characteristics and kinetic study of mixed pyrolysis of municipal solid waste. Journal of Southeast University 43:130-135. DOI: 10.3969/j.issn.1001-0505.2013.01.025 (in Chinese)

Du CY, Abdullah JJ, Greetham D, Fu, DN, Yu MY, Ren LW, Li S, Lu DN. 2018. Valorization 
448 of food waste into biofertiliser and its field application. Journal of Cleaner Production 187:273-284. DOI: 10.1016/j.jclepro.2018.03.211

450

451

452

453

454

455

456

457

458

459

460

461

462

463

464

465

466

467

468

Dusoruth V, Peterson HH. 2020. Food waste tendencies: Behavioral response to cosmetic deterioration of food. PLoS One 15:22. DOI:10.1371/journal.pone.02332870

Gallipoli A, Braguglia CM, Gianico A, Montecchio D, Pagliaccia P. 2020. Kitchen waste valorization through a mildtemperature pretreatment to enhance biogas production and fermentability: Kinetics study in mesophilic and thermophilic regimen. Journal of Environmental Sciences 89:167-179. DOI:10.1016/j.jes.2019.10.016

Ghinea C, Apostol LC, Prisacaru AE, Leahu A. 2019. Development of a model for food waste composting. Environmental Science and Pollution Research 26:4056-4069 doi:10.1007/s11356-018-3939-1

Giordano C, Alboni F, Falasconi L. 2019. Quantities, determinants, and awareness of households' food waste in Italy: A comparison between diary and questionnaires. Quantities Sustainability 11:15 doi:10.3390/su11123381

Gu BX, Jiang SQ, Wang HK, Wang ZB, Jia RF, Yang J, He S, Cheng R. 2017. Characterization, quantification and management of China's municipal solid waste in spatiotemporal distributions: A review. Waste Management 61:67-77. DOI:10.1016/j.wasman.2016.11.039

Guo JH, Liu XJ, Zhang Y, Shen JL, Han WX, Zhang WF, Christie P, Goulding KWT, Vitousek PM, Zhang FS. 2010. Significant acidification in major Chinese croplands. Science 327:1008-1010. DOI:10.1126/science. 1182570 
469 Guven H, Wang Z, Eriksson O. 2019. Evaluation of future food waste management alternatives 470 in Istanbul from the life cycle assessment perspective. Journal of Cleaner Production 239:12 doi:10.1016/j.jclepro.2019.117999

472

473

474

475

476

477

478

479

480

481

482

483

484

485

486

487

488

489

Han ZY, Dan Z, Shi GZ, Shen LK, Xu WL, Xie YH. 2015. Characteristics and management of domestic waste in a rural area of the Tibetan Plateau. Journal of the Air \& Waste Management Association 65:1365-1375. DOI:10.1080/10962247.2015.1078859

Han ZY, Ye CW, Zhang Y, Dan Z, Zou ZY, Liu D, Shi GZ. 2019. Characteristics and management modes of domestic waste in rural areas of developing countries: a case study of China. Environmental Science and Pollution Research 26:8485-8501.

DOI:10.1007/s11356-019-04289-w

Hansen LB, Termansen M, Hasler B. 2019. The potential for nitrogen abatement trading in agriculture: A hypothetical market experiment. Journal of Agricultural Economics 70:812839. DOI:10.1111/1477-9552.12319

Heidari A, Mirzaii F, Rahnama M, Alidoost F. 2020. A theoretical framework for explaining the determinants of food waste reduction in residential households: a case study of Mashhad, Iran. Environmental Science and Pollution Research 27:6774-6784 doi:10.1007/s11356019-06518-8

Hiramatsu A, Hara Y, Sekiyama M, Honda R, Chiemchaisri C. 2009. Municipal solid waste flow and waste generation characteristics in an urban-rural fringe area in Thailand. Waste Management \& Research 27:951-960. DOI:10.1177/0734242x09103819

Hou JQ, Li MX, Xi BD, Tan WB, Ding J, Hao Y, Liu DM, Liu HL. 2017. Short-duration 
hydrothermal fermentation of food waste: preparation of soil conditioner for amending organic-matter-impoverished arable soils. Environmental Science and Pollution Research 24:21283-21297. DOI:10.1007/s11356-017-9514-3

493

494

495

496

497

498

499

500

501

502

503

504

505

506

507

508

509

510

Huang KX, Wang JX, Bai JF, Qiu HG. 2013. Domestic solid waste discharge and its determinants in rural China. China Agricultural Economic Review 5:512-525. DOI:10.1108/caer-02-2012-0008

Jia X, Zhao B, Ren LH, Li MX, Zhang XH, Hou JQ, He L. 2019. Effects of food waste soil conditioner on organic carbon distribution in orchard soil. Research of Environmental Sciences 32:485-492. DOI: 10. 13198/j.issn.1001-6929.2018.06.23 (in Chinese)

Jiang Y, Dennehy C, Lawlor PG, Hu ZH, Yang QF, McCarthy G, Tan SP, Zhan XM, Gardiner GE. 2018. Inactivation of Salmonella during dry co-digestion of food waste and pig for manure. Waste Management 82:231-240. DOI:10.1016/j.wasman.2018.10.037

Lee, CH, Park SJ, Hwang H.Y, Kim MS, .Jung, HI, Luyima D, Hong SY, Oh TK, Kim SH. 2019. Effects of food waste compost on the shift of microbial community in water saturated and unsaturated soil condition. Applied Biological Chemistry 62:7 doi:10.1186/s13765-0190445-1

Li C. 2010. Application of native botanical materials in electroplating wastewater treatment. Plating \& Finishing 32:25-30 (in Chinese)

Li SF, Xu Z, Zhou HP, Wei GQ. 2020. A comparative study on the utilization of two kinds of organic wastes in vegetable planting. Vegetables 10:8-13 (in Chinese)

Li XR, Bi F, Han ZD, Qin Y, Wang HS, Wu WX. 2019. Garbage source classification 
511

512

513

514

515

516

517

518

519

520

521

522

523

524

525

526

527

528

529

530

531

performance, impact factor, and management strategy in rural areas of China: A case study in Hangzhou. Waste Management 89:313-321. DOI:10.1016/j.wasman.2019.04.020

Liu HY. 2016. Recycling and sorting of waste paper. Heilongjiang Pulp \& Paper 44:21-25 (in Chinese)

Liu J, Zhang J, Li DM, Xu CX, Xiang XJ. 2020. Differential responses of arbuscular mycorrhizal fungal communities to mineral and organic fertilization. Microbiology Open 9:10. DOI: $10.1002 / \mathrm{mbo} 3.920$

Liu JH, Li Q, Gu W, Wang C. 2019. The impact of consumption patterns on the generation of municipal solid waste in China: Evidences from provincial data. International Journal of Environmental Research and Public Health 19:1-19. DOI:10.3390/ijerph16101717

Liu SH. 2020. Chinese food chinese rice bowl. Grain Science and Technology and Economy 45:9-11 (in Chinese)

Liu XX. 2018. Turning waste into treasure-A discussion on the reuse technology of waste paper. China Resources Comprehensive Utilization 36:67-69. DOI:1008-9500(2018)11-0067-03 (in Chinese)

Lu CQ, Tian HQ. 2017. Global nitrogen and phosphorus fertilizer use for agriculture production in the past half century: shifted hot spots and nutrient imbalance. Earth System Science Data 9:181-192. DOI:10.5194/essd-9-181-2017

Ma J, Hipel KW, Hanson ML. 2018. An evaluation of the social dimensions in public participation in rural domestic waste source-separated collection in Guilin, China. Environmental Monitoring and Assessment 190:14. DOI:10.1007/s10661-017-6405-5 
Ma Y, Liu Y. 2019. Turning food waste to energy and resources towards a great environmental and economic sustainability: An innovative integrated biological approach. Biotechnology Advances 37:107414. DOI:10.1016/j.biotechadv.2019.06.013

Ministry of Housing and Urban-Rural Development of the People's Republic of China. China Statistical Yearbook on urban and rural construction 2011-2020 (in Chinese). Available online. 2011-2020. http://www.mohurd.gov.cn/xytj/t jzljsxytjgb/jstjnj/index.html.

National Bureau of Statistics of the People's Republic of China (NBS). China statistical Yearbook in 2020 (in Chinese). 2020. Available online, http://www. stats.gov.cn/tjsj/ndsj/2019/indexch.htm.

Parihar CM, Parihar MD, Sapkota TB, Nanwal RK, Singh AK, Jat SL, Nayak HS, Mahala DM, Singh LK, Kakraliya SK, Stirling CM, Jat ML. 2018. Long-term impact of conservation agriculture and diversified maize rotations on carbon pools and stocks, mineral nitrogen fractions and nitrous oxide fluxes in inceptisol of India. Science of the Total Environment 640:1382-1392. DOI:10.1016/j.scitotenv.2018.05.405

Paritosh K, Kushwaha SK, Yadav M, Pareek N, Chawade A, Vivekanand V. 2017. Food waste to energy: An overview of sustainable approaches for food waste management and nutrient recycling. Biomed Research International:19. DOI:10.1155/2017/2370927

Rao P, Rathod V. 2019. Valorization of food and agricultural waste: a step towards greener future. Chemical Record 19:1858-1871. DOI:10.1002/tcr.201800094

Rigby H, Smith SR. 2013. Nitrogen availability and indirect measurements of greenhouse gas 
emissions from aerobic and anaerobic biowaste digestates applied to agricultural soils. Waste Management 33:2641-2652. DOI: 10.1016/j.wasman.2013.08.005

Saad MFM, Rahman NA, Yusoff MZM. 2019. Hydrogen and methane production from codigestion of food waste and chicken manure. Polish Journal Of Environmental Studies 28:2805-2814. DOI:10.15244/pjoes/83670

Seo H, Cho K, Shin J, Lee M, Park J, Lee BC, Song KG. 2019. Linking process performances and core microbial community structures in anaerobic membrane bioreactor with rotatory disk (ARMBR) system fed with high-strength food waste recycling wastewater. Bioresource Technology 291:11 doi:10.1016/j.biortech.2019.121918

Shan GC, Xu JQ, Jiang ZW, Li MQ, Li QL. 2019. The transformation of different dissolved organic matter subfractions and distribution of heavy metals during food waste and sugarcane leaves co-composting. Waste Management 87:636-644.

DOI:10.1016/j.wasman.2019.03.005

Sharma LK, Bali SK. 2018. A review of methods to improve nitrogen use efficiency in agriculture. Sustainability 10:23. DOI:10.3390/su10010051

Shi XX, Zheng GD, Shao ZZ, Gao D. 2020. Effect of source-classified and mixed collection from residential household waste bins on the emission characteristics of volatile organic compounds. Science of the Total Environment 707:9. DOI:10.1016/j.scitotenv.2019.135478

Sindhu R, Gnansounou E, Rebello S, Binod P, Varjani S, Thakur IS, Nair RB, Pandey A. 2019. Conversion of food and kitchen waste to value-added products. Journal of Environmental Management 241:619-630. DOI:10.1016/j.jenvman.2019.02.053 
574 Song B, Nie LH, Yuan QN, Zhang X, Zhang GQ, Gao PX, Zhu JL. 2014. Effects of several

575 common kitchen wastes on the growth of Chlorophytum comosum. Journal of Agriculture

576 4:56-59 (in Chinese)

577

578

579

580

581

582

583

584

Stathopoulos CE. 2017. Utilisation of plant food. Waste Foods (Basel, Switzerland) 6 doi:10.3390/foods6060045

Stuart D, Houser M. 2018. Producing Compliant Polluters: Seed companies and nitrogen fertilizer application in US corn agriculture. Rural Sociology 83:857-881. DOI:10.1111/ruso.12212.

Sutton MA, Oenema O, Erisman JW, Leip A, van Grinsven H, Winiwarter W. 2011. Too much of a good thing. Nature 472:159-161. DOI:10.1038/472159a

The World Bank. Solid Waste Managementment 2018.

Tian GJ, Kong LQ, Liu XJ, Yuan WP. 2018. The spatio-temporal dynamic pattern of rural domestic solid waste discharge of China and its challenges. Environmental Science and Pollution Research 25:10115-10125. DOI:10.1007/s11356-017-1154-0

Urso JH, Gilbertson LM. 2018. Atom Conversion Efficiency: A new sustainability metric applied to nitrogen and phosphorus use in agriculture ACS sustain. Chemical Engineering Journal 6:4453-4463. DOI:10.1021/acssuschemeng.7b03600

von Massow M, Parizeau K, Gallant M, Wickson M, Haines J, Ma DWL, Wallace A, Carroll N, Duncan AM. 2019. Valuing the multiple impacts of household food. Waste Frontiers in Nutrition 6:17 doi:10.3389/fnut.2019.00143

Wang JH. 2018. Research on the efficiency of urban green innovation and its influencing factors. 
595

596

597

598

599

600

601

602

603

604

605

606

607

608

609

610

611

612

613

614

615

Xianan:Shaanxi Normal University (in Chinese)

Wang LE, Hou P, Liu X J, Cheng SK. 2018. The connotation and realization way of sustainable food consumption in China. Resources Science 40(8):1550-1559.

DOI:10.18402/resci.2018.08.06

Wang SG, Zeng Y. 2018. Ammonia emission mitigation in food waste composting: A review. Bioresource Technology 248:13-19. DOI:10.1016/j.biortech.2017.07.050

Wang TX. The food wasted can feed 300 million people every year in the country. China News Network. http://www. chinanews. Com/gn/news/2010/03-10/2161052.shtml.2010-03-10.

Waqas M, Nizami AS, Aburiazaiza AS, Barakat MA, Asam ZZ, Khattak B, Rashid MI. 2019. Untapped potential of zeolites in optimization of food waste composting. Journal of Environmental Management 241:99-112. DOI:10.1016/j.jenvman.2019.04.014

Williams SR, Zhu-Barker X, Lew S, Croze BJ, Fallan KR, Horwath WR. 2019. Impact of composting food waste with green waste on greenhouse gas emissions from compost windrows. Compost Science \& Utilization 27:35-45.

DOI:10.1080/1065657x.2018.1550023

Wu XH, Yue B, Huang QF, Wang Q, Li ZL, Wang YT, Yu JY. 2018. Investigation of the physical and chemical characteristics of rural solid waste in China and its spatiotemporal distributions. Environmental Science and Pollution Research 25:17330-17342. DOI:10.1007/s11356-018-1432-5

Xing BS, Han YL, Wang XC, Ma Jing, Cao SF, Li Q, Wen JW, Yuan HL. 2019. Cow manure as additive to a DMBR for stable and high-rate digestion of food waste: Performance and 
Xiong C. 2015. Experimental study on organic fertilizer production from kitchen waste by hydrothermal treatment. Hangzhou: Zhejiang University (in Chinese)

Xu HB, Hu JH, Liu HL, Li A, Jin LF, Liu JL. 2018. Experiment and thermodynamic analysis of the sawdust catalytic gasification with copper slag. Chemical Industry and Engineering Progress 35:3142-3148. DOI:10.16085/j.issn.1000-6613.2016.10.018 (in Chinese)

Yang F, Li GX, Yang QY, Luo WH. 2013. Effect of bulking agents on maturity and gaseous emissions during kitchen waste composting. Chemosphere 93:1393-1399. DOI:10.1016/j.chemosphere.2013.07.002

Yu XF, Guo LY, Jiang GM, Song YJ, Muminov MA. 2018. Advances of organic products over Ecologica Sinica 38:53-60. DOI:10.1016/j.chnaes.2018.01.009

Zeng J, Yue Fj, Li SL, Wang ZJ, Qin CQ, Wu QX, Xu S. 2020. Agriculture driven nitrogen wet Waste Management 58:369-375. DOI:10.1016/j.wasman.2016.08.022

Zhang LF. 2019. Research on the management of domestic waste disposal in Xiong'an. Shijiazhuang: Hebei University (in Chinese) 
637 future prospects of food waste research: a bibliometric analysis. Environmental Science and Pollution Research 25:24600-24610 doi:10.1007/s11356-018-2598-6

639 Zhang YF. 2019. Research on the management of domestic waste disposal in Xiong'an new 640 distric (in Chinese). Baoding: Hebei University (in Chinese)

641 Zhou Y, Selvam A, Wong JWC. 2018. Chinese medicinal herbal residues as a bulking agent for 642 food waste composting. Bioresource Technology 249:182-188.

643 DOI:10.1016/j.biortech.2017.09.212 
Figure 1

The biomass and nitrogen reservoir of urban and rural food waste in China from 2010 to 2019

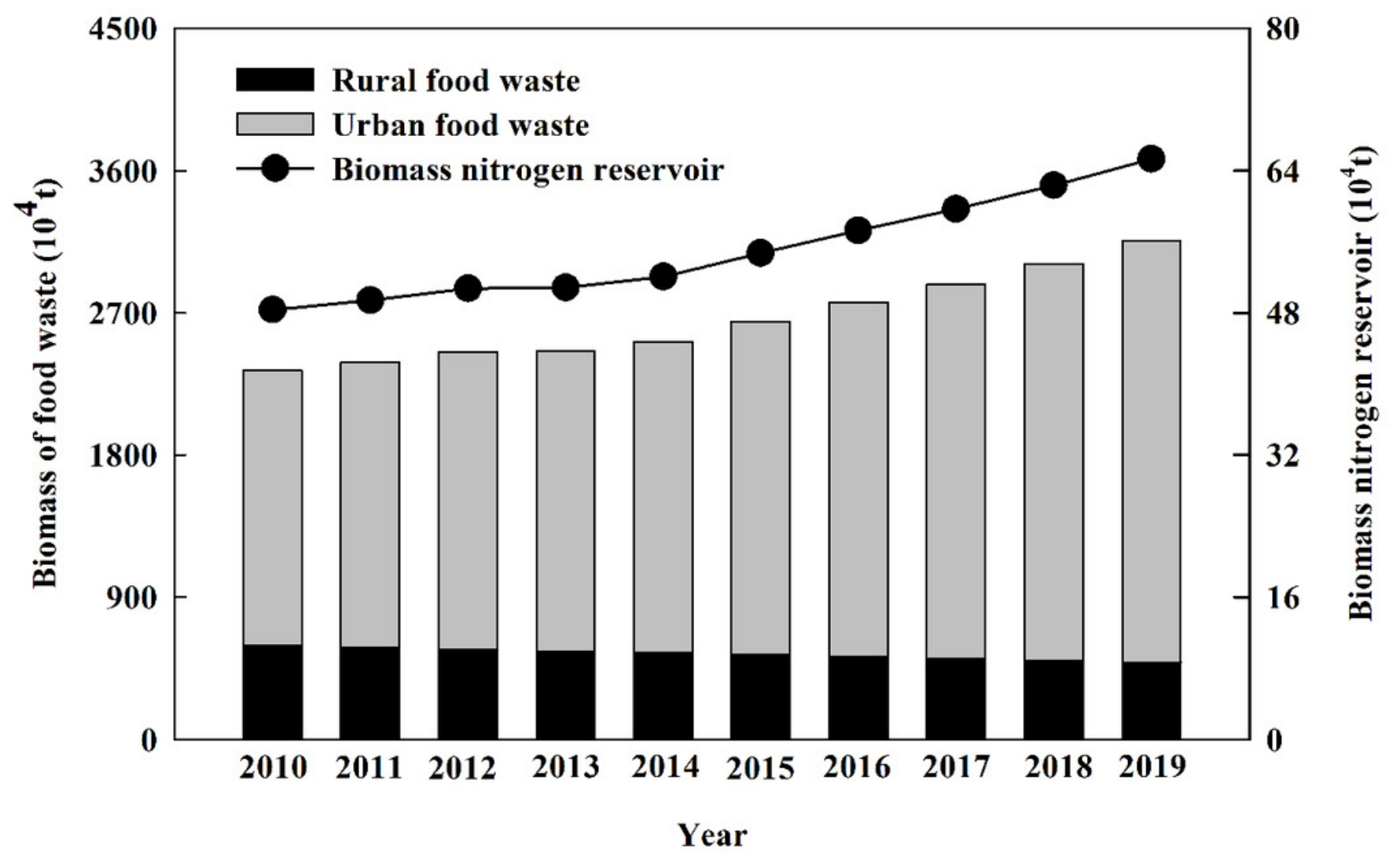


Figure 2

The biomass and nitrogen reservoir of urban and rural waste paper in China from 2010 to 2019

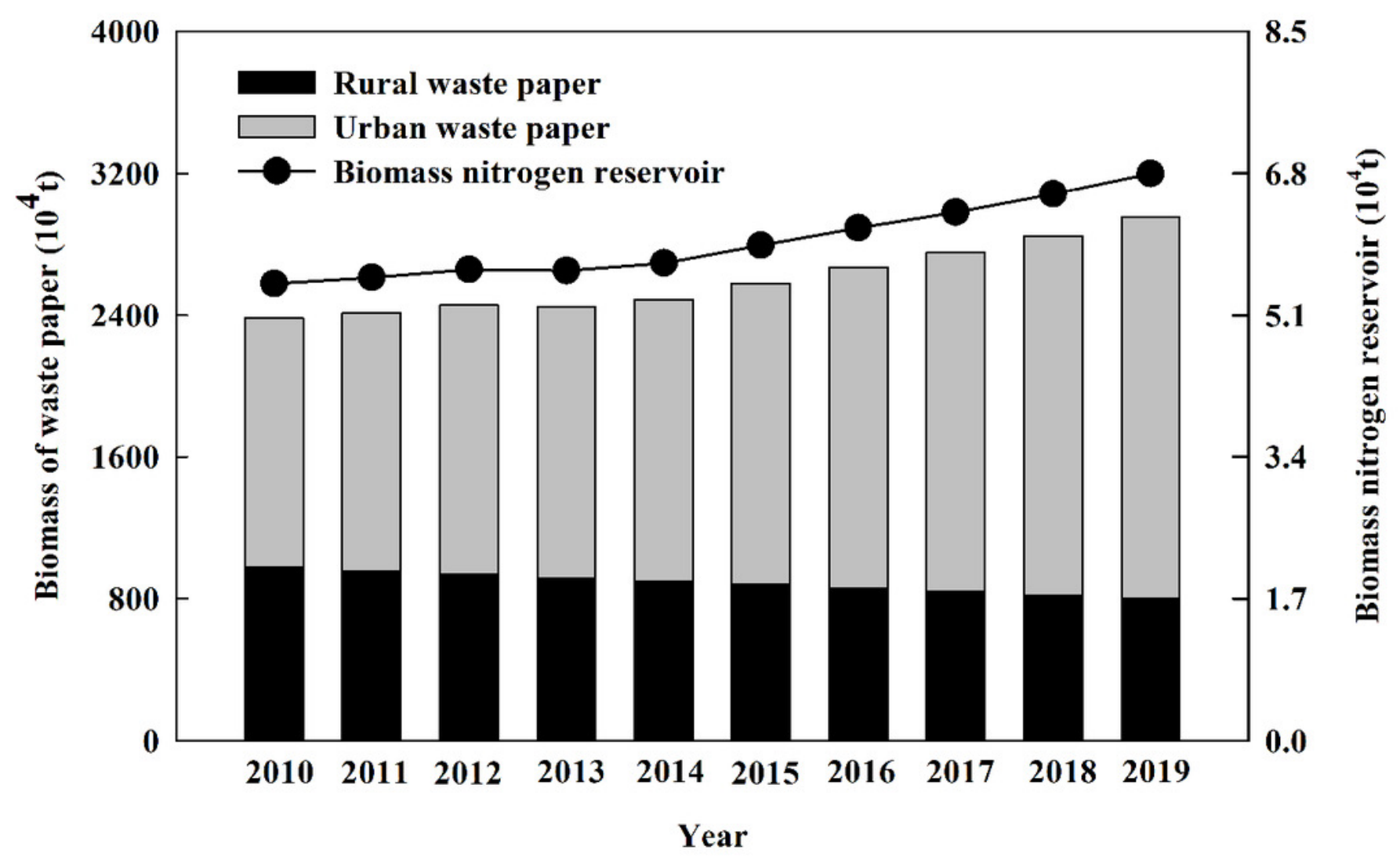


Figure 3

The biomass and nitrogen reservoir of urban and rural wood chips in China from 2010 to 2019

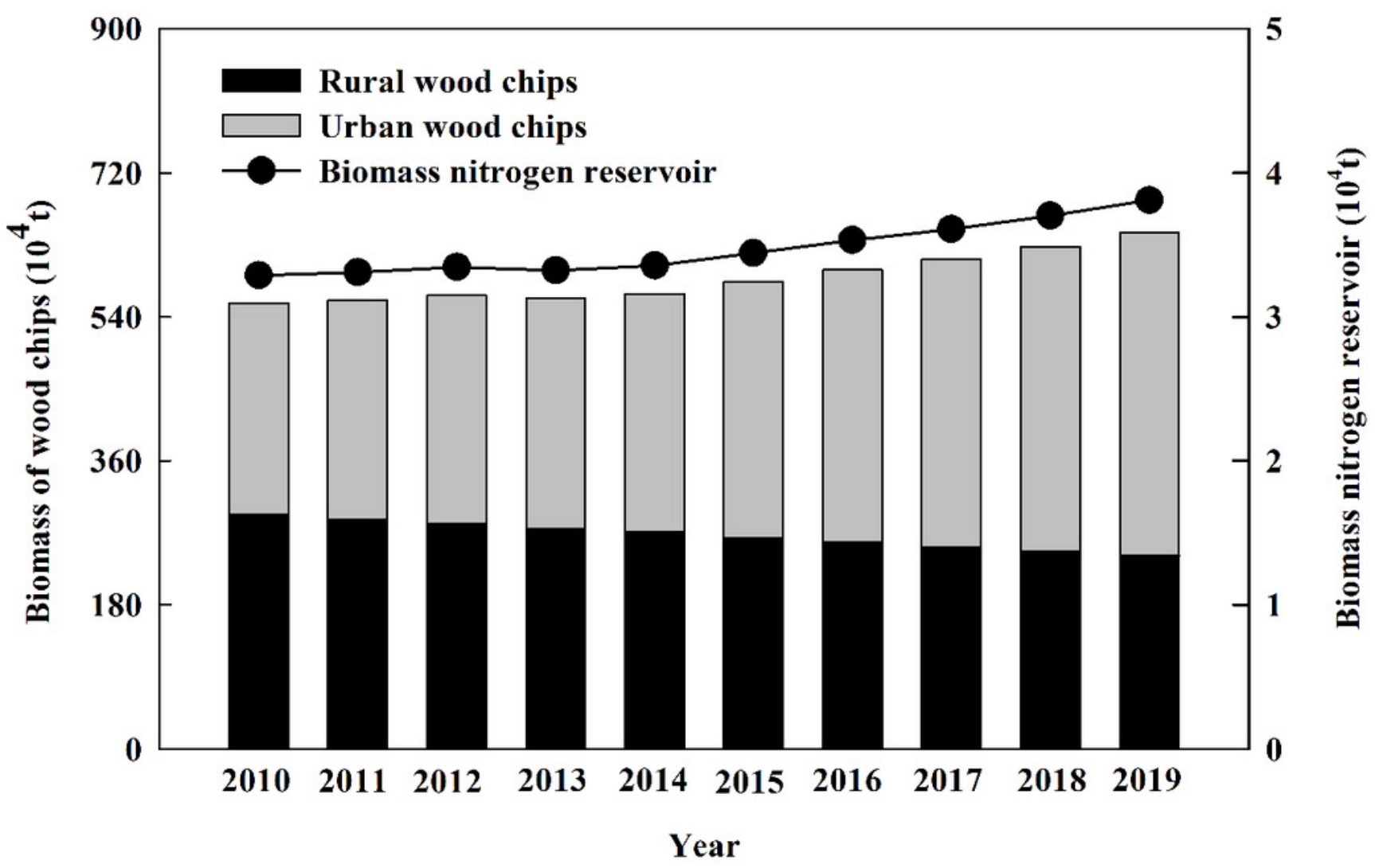


Figure 4

Changes of nitrogen reservoir and the proportion of biodegradable household garbage from 2010 to 2019 in China

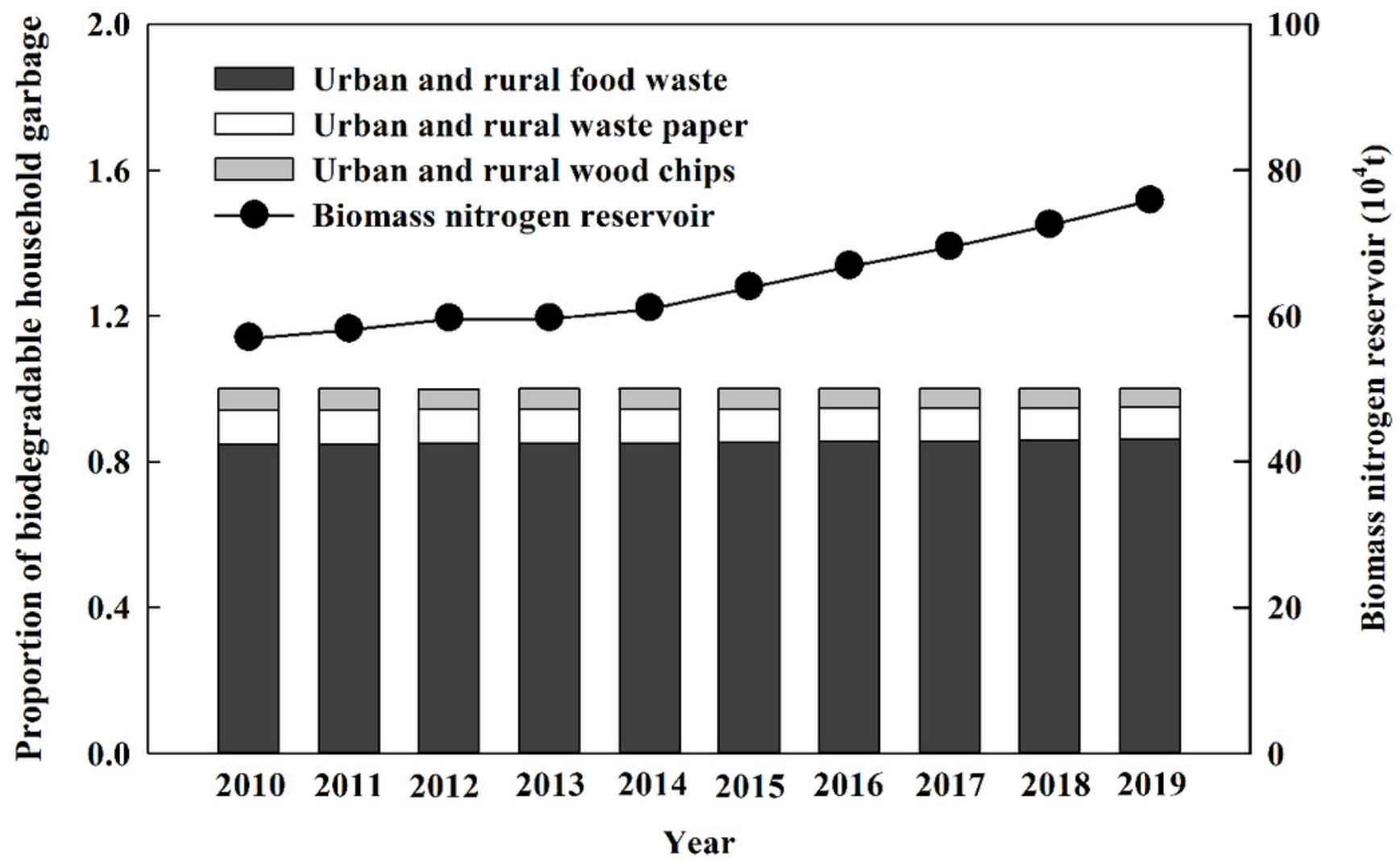


Figure 5

The relationship between per capital GDP and per capital discharge of food waste

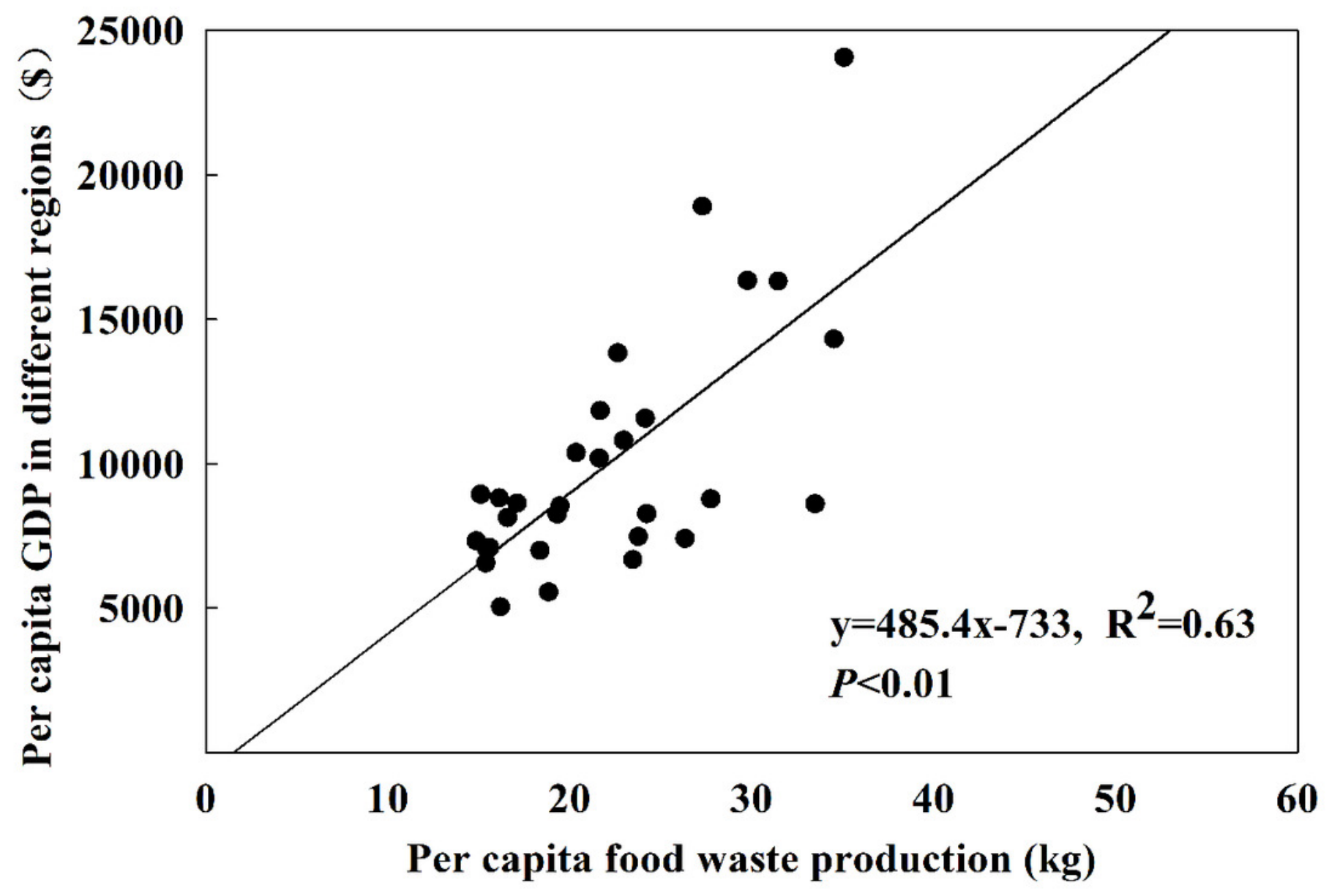




\section{Table $\mathbf{1}$ (on next page)}

Urban and rural household garbage resources in China from 2010 to 2019 (fresh weight) 
1 Table 1 Urban and rural household garbage resources in China from 2010 to 2019 (fresh

2 weight).

\begin{tabular}{|c|c|c|c|c|c|c|c|c|c|c|c|}
\hline \multicolumn{2}{|c|}{ Household garbage } & \multirow{2}{*}{$\begin{array}{c}2010 \\
15438\end{array}$} & \multirow{2}{*}{$\begin{array}{c}2011 \\
15734\end{array}$} & \multirow{2}{*}{$\begin{array}{c}2012 \\
15805\end{array}$} & \multirow{2}{*}{$\frac{2013}{16395}$} & \multirow{2}{*}{$\begin{array}{c}2014 \\
17081\end{array}$} & \multirow{2}{*}{$\begin{array}{c}2015 \\
17239\end{array}$} & \multirow{2}{*}{$\frac{2016}{17860}$} & \multirow{2}{*}{$\begin{array}{c}2017 \\
19142\end{array}$} & \multirow{2}{*}{$\begin{array}{l}2018 \\
20362\end{array}$} & \multirow{2}{*}{$\begin{array}{r}2019 \\
21521\end{array}$} \\
\hline Urban & Production $\left(10^{4} t\right)$ & & & & & & & & & & \\
\hline \multirow[t]{4}{*}{ Rural } & Population $\left(10^{4}\right)$ & 67113 & 65656 & 64222 & 62961 & 61866 & 60346 & 58973 & 57661 & 56401 & 55162 \\
\hline & Per capita daily (kg/d) & 0.4 & 0.4 & 0.4 & 0.4 & 0.4 & 0.4 & 0.4 & 0.4 & 0.4 & 0.4 \\
\hline & Days & 365 & 365 & 366 & 365 & 365 & 365 & 366 & 365 & 365 & 365 \\
\hline & Production $\left(10^{4} t\right)$ & 9798 & 9586 & 9402 & 9192 & 9032 & 8811 & 8634 & 8419 & 8235 & 8054 \\
\hline Total & Production $\left(10^{4} \mathrm{t}\right)$ & 25603 & 25981 & 26483 & 26431 & 26892 & 27953 & 28996 & 29940 & 31037 & 32260 \\
\hline
\end{tabular}




\section{Table 2 (on next page)}

Urban increase and rural decrease yearly rates of biodegradable household garbage resources in China from 2010 to 2019 
1 Table 2 Urban increase and rural decrease yearly rates of biodegradable household garbage 2 resources in China from 2010 to 2019

\begin{tabular}{lll}
\hline Year & \multicolumn{2}{c}{ Biodegradable household garbage } \\
\cline { 2 - 3 } & Urban yearly increase rates (\%) & Rural yearly decrease rates $(\%)$ \\
\hline $2010-2011$ & 3.73 & 2.17 \\
$2011-2012$ & 4.18 & 1.92 \\
$2012-2013$ & 0.93 & 2.23 \\
$2013-2014$ & 3.60 & 1.74 \\
$2014-2015$ & 7.18 & 2.46 \\
$2015-2016$ & 6.37 & 2.01 \\
$2016-2017$ & 5.69 & 2.49 \\
$2017-2018$ & 5.95 & 2.19 \\
$2018-2019$ & 6.16 & 2.20 \\
\hline
\end{tabular}

3 


\section{Table 3 (on next page)}

Urban and rural per capita biodegradable household garbage resources in seven regions of China in 2019 
1 Table 3 Urban and rural per capita biodegradable household garbage resources in seven regions 2 of China in 2019

\begin{tabular}{lllllllll}
\hline$\square$ & North & Northeast & East & Central & Southern & Southwest & Northwest \\
\hline Urban & Food waste $\left(10^{4} \mathrm{t}\right)$ & 331.42 & 219.45 & 884.92 & 318.36 & 451.82 & 292.54 & 165.08 \\
& Waste paper $\left(10^{4} \mathrm{t}\right)$ & 267.59 & 177.18 & 714.49 & 257.05 & 364.80 & 236.20 & 133.29 \\
& Wood chips $\left(10^{4} \mathrm{t}\right)$ & 50.23 & 33.26 & 134.13 & 48.25 & 68.48 & 44.34 & 25.02 \\
\multirow{2}{*}{ Rural } & Food waste $\left(10^{4} \mathrm{t}\right)$ & 54.94 & 35.23 & 127.69 & 86.63 & 54.08 & 83.92 & 41.62 \\
& Waste paper $\left(10^{4} \mathrm{t}\right)$ & 90.21 & 57.85 & 209.66 & 142.24 & 88.79 & 137.79 & 68.33 \\
& Wood chips $\left(10^{4} \mathrm{t}\right)$ & 27.14 & 17.40 & 63.07 & 42.79 & 26.71 & 41.45 & 20.56 \\
& Biodegradable household & & & & & & & \\
\multirow{2}{*}{ Total } & garbage $\left(10^{4} \mathrm{t}\right)$ & 821.53 & 540.37 & 2133.95 & 895.34 & 1054.68 & 836.24 & 453.89 \\
& Population $\left(10^{4}\right)$ & 17577 & 10794 & 41423 & 22485 & 17426 & 20331 & 10349 \\
& Per capita $\left(\mathrm{kg} \mathrm{a}^{-1}\right)$ & 46.74 & 50.06 & 51.52 & 39.82 & 60.52 & 41.13 & 43.86 \\
\hline
\end{tabular}

3 
Table 4 (on next page)

Gross domestic product (GDP) and food waste resources in 2019 in China 
$1 \quad$ Table 4

2 Gross domestic product (GDP) and food waste resources in 2019 in China

\begin{tabular}{|c|c|c|c|c|c|}
\hline Province & $\begin{array}{l}\text { Population } \\
\left(10^{4}\right)\end{array}$ & $\begin{array}{l}\text { GDP } \\
\text { (billion, \$) }\end{array}$ & $\begin{array}{l}\text { Urban and rural food waste } \\
\text { production }\left(10^{4} t\right)\end{array}$ & $\begin{array}{l}\text { Per capita } \\
\text { GDP(\$) }\end{array}$ & Per capita food waste(kg) \\
\hline Guangdong & 11521 & 1648.74 & 397.92 & 14310.74 & 34.54 \\
\hline Jiangsu & 8070 & 1525.63 & 220.35 & 18904.96 & 27.30 \\
\hline Shandong & 10070 & 1088.24 & 231.16 & 10806.75 & 22.96 \\
\hline Zhejiang & $\mathbf{5 8 5 0}$ & 954.78 & 184.11 & 16321.03 & 31.47 \\
\hline Henan & 9640 & 830.86 & 164.94 & 8618.88 & 17.11 \\
\hline Sichuan & 8375 & 713.82 & 163.01 & 8523.22 & 19.46 \\
\hline Hubei & 5927 & 701.76 & 128.43 & 11840.05 & 21.67 \\
\hline Fujian & 3973 & 649.18 & 118.32 & 16339.79 & 29.78 \\
\hline Hunan & 6918 & 608.71 & 111.63 & 8798.93 & 16.14 \\
\hline Shanghai & 2428 & 584.26 & 85.21 & 24063.43 & 35.09 \\
\hline Anhui & 6366 & 568.32 & 96.09 & 8927.43 & 15.09 \\
\hline Beijing & 2154 & 541.63 & 113.95 & 25145.31 & 52.90 \\
\hline Hebei & 7592 & 537.55 & 116.87 & 7080.48 & 15.39 \\
\hline Shaanxi & 3876 & 394.96 & 83.76 & 10189.89 & 21.61 \\
\hline Liaoning & 4352 & 381.43 & 120.84 & 8764.48 & 27.77 \\
\hline Jiangxi & 4666 & 379.11 & 77.37 & 8124.95 & 16.58 \\
\hline Chongqing & 3124 & 361.47 & 75.47 & 11570.74 & 24.16 \\
\hline Yunnan & 4858 & 355.62 & 72.20 & 7320.30 & 14.86 \\
\hline Guangxi & 4960 & 325.20 & 76.31 & 6556.45 & 15.39 \\
\hline Inner Mongolia & 2540 & 263.57 & 51.70 & 10376.77 & 20.35 \\
\hline Shanxi & 3729 & 260.73 & 68.48 & 6991.95 & 18.36 \\
\hline Guizhou & 3623 & 256.78 & 56.52 & 7087.50 & 15.60 \\
\hline Tianjin & 1562 & 215.98 & 35.36 & 13827.14 & 22.64 \\
\hline Heilongjiang & 3751 & 208.45 & 70.67 & 5557.18 & 18.84 \\
\hline Xinjiang & 2523 & 208.21 & 48.75 & 8252.48 & 19.32 \\
\hline Jilin & 2691 & 179.57 & 63.16 & 6672.98 & 23.47 \\
\hline Gansu & 2647 & 133.50 & 42.88 & 5043.45 & 16.20 \\
\hline Hainan & 945 & 81.29 & 31.66 & 8602.12 & 33.50 \\
\hline Ningxia & 695 & $\mathbf{5 7 . 4 0}$ & 16.85 & 8258.99 & 24.24 \\
\hline Qinghai & 608 & 45.42 & 14.45 & 7470.39 & 23.77 \\
\hline Tibet & 351 & 26.00 & 9.25 & 7407.41 & 26.35 \\
\hline
\end{tabular}

3 Note: $\$ 1.0=6.5305$ Chinese Yuan. 